Editorial

\title{
Thematic Issue on The End of Television (Not Yet): Editor's Introduction
}

\author{
Milly Buonanno \\ Department of Communication and Social Research, La Sapienza University of Roma, 00198 Roma, Italy; \\ E-Mail: milly.buonanno@uniroma1.it
}

Submitted: 1 May 2016 | Published: 14 July 2016

\begin{abstract}
This editorial provides background considerations for challenging the long taken-for-granted narrative of the passing of television in the digital era, thus inviting scholars to re-interrogate the place of the medium in the new technologysaturated environment from perspectives that are not informed by the unquestioned assumption that the age of television is over.
\end{abstract}

\section{Keywords}

broadcasting; change; continuity; digital; microcasting; obsolescence

\section{Issue}

This editorial is part of the issue "(Not Yet) the End of Television", edited by Milly Buonanno (University of Roma "La Sapienza", Italy).

(C) 2016 by the author; licensee Cogitatio (Lisbon, Portugal). This article is licensed under a Creative Commons Attribution 4.0 International License (CC BY).

In November 2014 Netflix CEO pronounced that television will be dead by 2030 . Hardly a new prediction, in actual fact, as statements of the soon-to-come collapse of broadcast TV have resounded in media pundits declarations since mid-Eighties. In turn the academywhich "every decade or so...is gripped by a fascination" (Livingstone, 2008, p. vii) with some new developments-has not remained immune to this same tendency. Media and cultural studies' fascination with technological transformations in the digital age, and the ensuing establishment of the (hierarchized) distinction between new media and old media, has in fact turned the obsolescence of television as we knew it into a key issue in early 2000 s years, thus making 'the end of TV" a familiar trope in scholarly discourses (Katz \& Scannel, 2009).

The passing of the broadcast era is being approached from two different perspectives, arousing opposing feelings of anxiety or satisfaction. The leading cultural studies scholar Graeme Turner has coined the definitions of 'broadcast pessimism' and 'digital optimism' (Turner \& Tay, 2010, p. 32), to encapsulate the two diverging standpoints. The proponents of broadcast pessimism complain that we are witnessing the inexorable obsolescence of traditional television-the television of sharedness, of family togethernessunder the disrupting, disuniting impact of media digitization. The digital optimists, on the contrary, welcome the rise of the post-broadcast era which-by disclosing an unprecedented range of contents, and allowing unrestrained time, space and modes of access to an array of platforms, screens, outputs-is deemed to democratically satisfy individual needs and demands of free choice and control over television experience. Yet the two antithetical perspectives converge to provide the same diagnosis that television is over.

Is television really dying? In a sense, we could say that television has never been so healthy and triumphant as nowadays: it has entered an age of 'plenty' (Ellis, 2000), characterized by unceasing proliferation of channels, uncontainable spread of output across media, screens, platforms, and national and transnational phenomena of fully-immersive, addictive fandom that was unthinkable in the old days when audiences were known as passive 'couch potatoes'. But on the other hand it might appear that owing precisely to the transformation undergone by the medium in the digital age, television as we know it is definitely coming to an end.

Worries about the disappearance of television, manifested by the broadcast pessimists, are hardly an 
unprecedented cultural phenomenon. As the wonderful book by Kathleen Fitzpatrick (2006) compellingly demonstrates, "the anxiety of obsolescence" has been a regular feature of the history of almost all the technologies and cultural forms of modernity, and has concerned from time to time novel, movie, radio, press, painting, photography etc. (all of which are still with us, albeit reshaped). In reality, the anxiety of obsolescence (or the opposite, the hunger: a point I will return to later) is perhaps less interesting for its alleged capacity to identify endangered technologies and cultural forms than for what it discloses about the way we conceive of those forms and envisage their possible evolution. It may be the case, for instance, that worries about the death of television help to unveil underlying essentialist conceptions of the medium, tending to solidify its nature into a set of given and unchanging characteristics: essentialist visions that resist coming to terms with processes of becoming. Further interesting and consequential aspect: as suggested by the Thomas theorem (Thomas \& Thomas, 1928), discourses on the demise of TV end up by conferring on their subject a status of reality. In fact, whether this 'definition of the situation' emanates from broadcast pessimism or digital optimism, it achieves to bring into existence the 'epochal phenomenon' of the end of television, and to validate the largely taken-for-granted assumption that the broadcast era has definitely given way, for better (the optimists) or for worse (the pessimists), to the present post-broadcast, post-network era.

Writing about literary fiction Frank Kermode affirmed that as readers "we hunger for ends and for crises" (Kermode, 1996, p. 5). In the context of Kermode's discourse hunger for ends refers to a sense-making process; but the expression can be appropriated in its plain meaning as 'longing for the end/demise' of somebody or something, to point out a peculiar feature of pronouncements and discourses concerning the passing of television. Predictions and statements of facts (real or presumed) that over the entire history of the media have coalesced into the discursive formations of the demise of the book, the movie, the press, have usually entailed worries, anxieties, mourning, eulogies, in short sorrow on the loss. Only when it comes to television does an ambivalence emerges, since alongside of the 'anxiety of obsolescence' a 'hunger for obsolescence' also takes shape and place, engendering-partly in academia, mainly in journalism, industry, public opinion: wherever the digital optimism has successfully taken hold-its own discursive formation, replete with celebratory statements of the soon-to-come or already-come-true collapse of broadcast TV, and with vibrant hopes of a better life after television, as predicted by George Gilder since midEighties (Gilder, 1985). What we are dealing here is probably the effect of two mutually reinforcing cultural stances: the 'modernist obsession for innovation and novelty' (Mulgan, 1990, p. 18), which fuels the highest expectations towards the new digital environment with its cornucopia of technologies of agency and liberation; and the "rejection and denigration" (Newman \& Levine, 2012, p. 2) that cultural élites have long expressed towards broadcast Tv, as a low-quality medium suited to passive mass-audiences.

In keeping with the hunger for television obsolescence, the enduring 'substitution approach' so often prevailing in discussions about the media and their evolutionary steps has expressed itself all too easily in declarations, predictions and expectations concerning the imminent demise of broadcasting. By substitution approach I refer to the intellectual penchant-to be found well beyond media studies-of conceiving processes of change and development in terms of displacement of the 'old' by the 'new'. U. Beck has defined this 'either-or' stance as "the mode of exclusive distinction", as opposed to "the mode of inclusive distinction" that accommodates co-existence and overlapping of differents phases, forms and directions of becoming (Beck, 2003), rather than postulating an inevitable sequence of obsolescence and replacement. The inescapability of such sequence is never so taken for granted as when the drivers of the change are believed to be the new technologies, whether this suggests pessimistic or optimistic predictions. Then, whereas broadcast pessimists mourn the loss of the television's ability to address the national community, putting the blame on the fragmentation brought about by media digitization, the optimists - who have on their side the digital orthodoxy enthusiastically embraced by conventional wisdom-celebrate the much awaited decline of a top-down centralized medium, superseded by a more progressive delivery system attuned to viewers' specific tastes and interests.

This is certainly not to deny that broadcast television has been deeply involved in processes of change and even of 're-invention' (Turner, 2015) that have thoroughly reshaped the contemporary media environment, of which the new media are a crucially distinctive component (not the only one that matters, though). However there seem to be no signs anywhere that the so-called 'old television' has been, or is in the process of being dislodged by the growing array of niche channels, new screens, digital platforms, streaming services, social networks and more besides. If we resist the tentation to conceive of the media, and namely the television becoming as a clash of old and new, where the old is sooner or later destined to surrender to the overwhelming advance of the new, we can find evidence that in contemporary media landscapes long established technologies and cultural forms can and do coexist in interaction and combination with their emerging counterparts, helping to put at users disposal a range of suitable resources and capacities to accommodate a plurality of habits and experi- 
ences of media consumption. Actually the postbroadcast age offers the conditions of possibility not only of unheard plenty of choice-which has not gone without its own rethoric of liberation and control-but, even more important, of diversified practices of television access and viewing. In particular, time-shifting and place-shifting options enabled by digital technologies allow for television contents to be accessed and watched at will 'anytime-anywhere' on multiple available platforms and screens. This trend towards an extremely individualized and customized mode of accessing and watching television has suggested definitions like as microcasting (Gillan, 2011) or personcasting (Lotz, 2007); and has not surprisingly strengthened pessimistic and optimistic ideas that broadcast television is definitely coming to an end.

But we should be wary of confusing condition of possibilities with determinants, shifts with reversals, additions with substitutions. For conditions of possibility to be actualized, many societal, cultural, economic factors must come into play, well beyond the 'technological magic'. And it remains to be seen whether emerging trends, embraced by enthusiastic early adopters, will pave the way to a new mainstream/longterm shift or will remain a minority phenomenon, or a situational one: id est a phenomenon mostly pertaining to the youth and young adulthood phases of the lifecourse (Frolova, 2016; Gillan, 2011).

Our understanding of the present-day television would benefit from looking for continuities and not just for breaks between the old and the new, from drawing attention to resilience, re-adaptations, strategies of coexistence and complementarity between media past and present, rather than giving pride of place to ruptures, obsolescence, substitutions. For instance: the somewhat dystopian vision of an atomized audience made up of monadic and nomadic viewers is tempered with-if not contradicted by-the diffused evidence that the desire and the practice of sharing media experiences remain crucial even in digital environment. Nor the appeal of 'appointment television' has vanished altogether, as it continues to have an impact (especially but not esclusively) on fans' practices, to the extent that watching television simultaneously (inside or outside the box) gives viewers the chance and the pleasure to partecipate in on-line first-conversations on the show 'as-it-airs' live.

Television may well have lost centrality (not everywhere, though) in the post-broadcast age but ultimately it is still with us, part and parcel of an expanded media environment in which the old media persistence meets the new media revolution.

Admittedly, announcements of the end of TV have ceased to resound in academic circles over the last few years (Lotz, 2014), and signals of incipient researcher's interest in the survival of television in the digital world are now emerging (Jacobs \& Bonner, 2016). However the bulk of contemporary media research confirms the observation that "academic engagement with media has always been concerned with the shock of the new" (Scannell, 2009, p. 220). Furthermore, media studies programs in a great many universities around the world are largely informed by "the assumption that the age of traditional media-especially television-is over" (Turner, 2015, p. 129). Such assumption is hardly questioned in the conventional wisdom about the current media age.

On these premises, Media and communication has invited media scholars to engage in a refreshing debate on the supposed, feared or hoped for, end of television as we knew it. The articles published in this special issue provide contextualized insights on what is television today in a range of specific locations (from Norway to Germany to Philippines to Mexico to Australia and more besides). In so doing, they help to reinvigorate our awareness about the resilience and the adaptability to change of an old medium that "has been and is always becoming" (Newcomb, 1996, p. XIX).

\section{Conflict of Interests}

The author declares no conflict of interests.

\section{References}

Beck, U. (2003). La società cosmopolita. Bologna, Italia: II Mulino.

Ellis, J. (2000). Seeing things. London: I.B. Tauris.

Fitzpatrick, K. (2006). The anxiety of obsolescence: The American novel in the age of television. Nashville, TN: Vanderbilt University Press.

Frolova, K. (2016). Watching television, a matter of life course. CST online. Retrieved from http://cstonline. tv/watching-tv

Gilder, G. (1985). Life after television: The coming transformation of media and American life. New York: W.W. Norton \& Company.

Gillan, J. (2011). Television and new media. Must-click tv. London: Routledge.

Jacobs, J., \& Bonner, F. (in press). The persistence of television: The case of the good life. Critical Studies in Television, 11.

Katz, E., \& Scannell, P. (Eds.). (2009). The end of television? Its impact on the world (so far). London, UK: Sage.

Kermode, F. (1966). The sense of an ending. Oxford, UK: Oxford University Press.

Livingstone, S. (2008). Preface. In N. Carpentier \& B. de Cleen (Eds.), Participation and media production (pp. vii-ix). Newcastle, UK: Cambridge Scholars Pubishing

Lotz, A. (2007). The television will be revolutioned. New York: New York University Press.

Lotz, A. (2014). The television will be revolutioned (2nd ed.). New York: New York University Press. 
Mulgan, G. (Ed.). (1990). The question of quality. London, UK: BFI Publishing.

Newcomb, H. (1996). The encyclopedia of television. Chicago, IL: Fitzroy-Dearborn Pub.

Newman, M. Z., \& Levine, E. (2011). Legitimating television. London: Routledge.

Scannell, P. (2009). The dialectic of time and television. In E. Katz \& P. Scannell (Eds.), The end of television? Its impact on the world (so far) (pp. 219-233). Lon- don, UK: Sage.

Thomas, W. I., \& Thomas, D. S. (1928). The child in America: Behavior problems and programs. New York: Knopf.

Turner, G. (2015). Re-inventing the media. London: Routledge.

Turner, G., \& Tay, J. (2010). Not the apocalypse: Television future in the digital age. International Journal of Digital Television, 1(1), 31-50.

\section{About the Author}

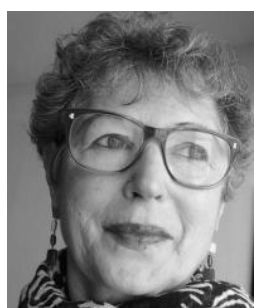

\section{Milly Buonanno}

Milly Buonanno is Professore Benemerita at La Sapienza University of Roma where she held the chair of Television Studies until 2014. She is currently the co-director of the research programme GEMMA (Gender and Media Matters) at the Department of Communication and Social Research (La Sapienza) and the director of the independent research project Observatory of Italian TV Drama. Her scholarship includes television theory and history, TV drama, feminist media studies, journalism. She is the author and the editor of more than fifty books. 